\title{
Does E-government Trust in e-Commerce when Investigating Trust? A Review of Trust Literature in E-Commerce and e- government Domains
}

\author{
Matti Mäntymäki \\ Turku School of Economics, Information Systems Science \\ Rehtorinpellonkatu 3, FI-20500 Turku, Finland \\ matti.mantymaki@tse.fi
}

\begin{abstract}
Trust has been acknowledged to be an important determinant of e-commerce acceptance. Therefore, understanding the nature and importance of trust is momentous in promoting e-government adoption. This paper reviews the trust discussion in business-to-consumer (B2C) e-commerce and government-to-individuals (G2IS) e-government. The aim of the paper is to identify potential differences as well as common denominators in order to introduce aspects that could potentially mutually benefit the research in the e-government and e-commerce domains. The main findings of the study are: 1 . both domains trust largely conceptualize as multidimensional construct. 2 . In the e-government field, trust is more often also empirically investigated as more than only one variable. 3. In the e-government literature, two main discourses related to trust were identified; trust in government in general, and trust in egovernment, referring to the technology aspects.
\end{abstract}

\section{Introduction}

Trust has been identified as an important factor in explaining customer's adoption of e-commerce and e-services.[1][2; 3] Pavlou and Fygenson $(2006,133)$ articulated in their study on $\mathrm{B} 2 \mathrm{C}$ e-commerce trust being perhaps the most interesting and empirically influential belief associated with getting information and purchasing products.[4]As stated by numerous authors, trust has been in the interest of several disciplines such as marketing, social psychology, sociology, management and marketing. $[5][2]$

Please use the following format when citing this chapter:

Mäntymäki, M., 2008, in IFIP International Federation for Information Processing, Volume 286; Towards Sustainable Society on Ubiquitous Networks, eds. Oya, M., Uda, R., Yasunobu, C., (Boston: Springer), pp. 253-264. 
The multi-dimensional of trust nature has been widely acknowledged [cf. e.g. 6]. Moreover, the conceptual complexity and thus the difficulties in finding a universal definition of trust have been addressed. [5] Despite these challenges, numerous studies in the e-commerce domain have contributed to increasing understanding on the nature and role of trust as well as its antecedents and consequences.

According to OECD (2003), e-government can be defined as "the use of ICTs, and particularly the Internet, as a tool to achieve better government". According to Lee, Tan, Xin and Trimi (2005) e-government is mainly concerned with providing high quality public services and value-added information to citizens.[9] In this study, ecommerce is defined rather broadly to encompass products and services

E-government has become an emerging field of research in the recent years. [7] Egovernment can be categorized in several ways, depending on the services offered and the target group of the offering. In this paper, we conceptualize e-government as the services that a governmental organization provides to individuals, referring to the categorization (G2IS) by Bélanger \& Hiller (2006).[8]

This paper investigates the trust literature in business-to-consumer (B2C) ecommerce and G2IS e-government fields of research. The aim is to identify potential differences as well as common denominators in order to introduce aspects that could potentially mutually benefit the research in the e-government and e-commerce domains. Thus, the paper contributes the e-government research by presenting an overview of the trust discussion within the domain and reflecting it to the respective literature from e-commerce. In practical terms, this is done by reviewing prior literature and presenting the findings in a structured form.

This study focuses on business-to-consumer (B2C) e-commerce and e-services. Similarly, the e-government domain is restricted to electronic services the government provides to citizens. Thus, services targeted to corporate customers (B2B and $\mathrm{G} 2 \mathrm{~B}$ ) are excluded from this study, as well as $\mathrm{C} 2 \mathrm{C}$ e-commerce.

\section{Trust in B2C e-Commerce and G2IS e-Government Literature}

As stated by Cheung et al $(2005,8)$, trust and perceived risk have been extensively investigated in relation to online purchase intentions.[10] IT acceptance has evolved as one of the most influential streams of research within the IS discipline [11]Several models have been developed to investigate and explain users' acceptance of new technologies[12; 13] However, in the IS research IS continuance and post-adoption behavior have become an emergent topic in the recent years which is also reflected in the reviewed trust literature. $[14 ; 15][16 ; 17]$

In ProQuest database a search using terms 'e-commerce' and 'trust' returns 1745 results, when limiting the search to academic articles the number of hits drops to 166. Conducting the search with 'e-government' and 'trust' the number total number of hits is 65 of which 18 are peer reviewed.

In the first round of the review, a keyword-based search was done in ProQuest/Abi/Inform, EbscoHost, Emerald and Elsevier ScienceDirect databases. Key- 
words 'trust' and 'e-government', 'trust' and electronic government', and finally, 'trust', 'government', and 'internet' were used. The first round of the review revealed that the academic discussion around e-government is fragmented across several forums. Therefore, two one dedicated e-government journals, Electronic Government, and International Journal and Electronic Journal of e-Government were included in the second round consisting of systematic review of the key publications as suggested by Webster \& Watson (2002)[18]. The review of e-commerce trust literature was done solely using keywords 'trust' and 'e-commerce' and 'trust' and 'electronic commerce'.

The reviewed e-commerce trust literature has been divided into three rather wide categories, studies discussing trust in e-commerce adoption and studies focusing on ongoing customer relationships after the initial adoption or acceptance has taken place, i.e. the post-adoption phase. The third category consists of literature reviews and conceptual papers. Self-evidently, the table does not contain all the literature that has been published, but the purpose is to give an overview of trust literature in the ecommerce domain. The aim of the categorization is used to somewhat compress and systematize the way the results are presented. The reviewed e-commerce trust literature is presented in tables $1,2 \& 3$ and the e-government literature in table 4 . 
Table 1. B2C e-commerce studies focusing on trust in initial acceptance

\begin{tabular}{|c|c|c|c|}
\hline $\begin{array}{l}\text { Studies on } \\
\text { adoption and } \\
\text { acceptance }\end{array}$ & View of trust & Findings & $\begin{array}{l}\text { Theoreti- } \\
\text { cal frame- } \\
\text { work }\end{array}$ \\
\hline $\begin{array}{l}\text { Pavlou [3] } \\
\text { Lim et al. } \\
\text { (2006)[19] } \\
\text { Pavlou et al. } \\
\text { (2006)[4] } \\
\text { Gefen et } \\
\text { al.(2003)[21] } \\
\text { Gefen \& Straub } \\
\text { (2003)[22] } \\
\text { Pavlou et. } \\
\text { al. (2007)[23] } \\
\text { Hampton-Sosa } \\
\text { \& Koufaris } \\
\text { (2005) [20] } \\
\text { Bhattacherjee } \\
\text { (2002)[1] } \\
\text { McKnight et al. } \\
\text { (2002)[6] }\end{array}$ & $\begin{array}{l}\text { Set of trusting } \\
\text { beliefs, opera- } \\
\text { tionalized as a } \\
\text { single variable } \\
\text { [3] } \\
\text { Trusting belifes + } \\
\text { trust propensity } \\
\text { as variables [20] } \\
\text { Multidimen- } \\
\text { sional, Also op- } \\
\text { erationalized as } \\
\text { multidimensional } \\
\text { [1] [6] }\end{array}$ & $\begin{array}{l}\text { TAM+trust+risk determinants of pur- } \\
\text { chase intentions and actual purchases } \\
\text { [3] } \\
\text { Trust increases willingness to buy [19] } \\
\text { Trust influences attitudes and control- } \\
\text { lability over getting information and } \\
\text { purchasing [4] } \\
\text { Trust integrated to TAM [21] [22] } \\
\text { Trust impacts purchase intentions in- } \\
\text { directly through perceived uncertainty } \\
\text { [23] } \\
\text { Initial trust as a mediator between web } \\
\text { site appeal and usefulness and inten- } \\
\text { tion to use a web site, trust propensity } \\
\text { an antecedent of initial trust [20] } \\
\text { Develops and test a scale for measur- } \\
\text { ing trust [1] } \\
\text { Familiarity Willingness to transact [1] } \\
\text { Tests and validates the framework de- } \\
\text { veloped by McKnight [6] }\end{array}$ & $\begin{array}{l}\text { TAM [3] } \\
\text { TRA [19] } \\
\text { TPB [4] } \\
\text { TAM [21] } \\
\text { [22] } \\
\text { Principal- } \\
\text { agent the- } \\
\text { ory } \\
\text { [23] } \\
\text { TAM [20] } \\
\text { Trust lit- } \\
\text { erature } \\
\text { from sev- } \\
\text { eral disci- } \\
\text { plines } \\
\text { TRA [6] }\end{array}$ \\
\hline
\end{tabular}


st Literature in E-Commerce and E-Government Domains

Table 2. B2C e-commerce studies focusing on trust after the initial acceptance

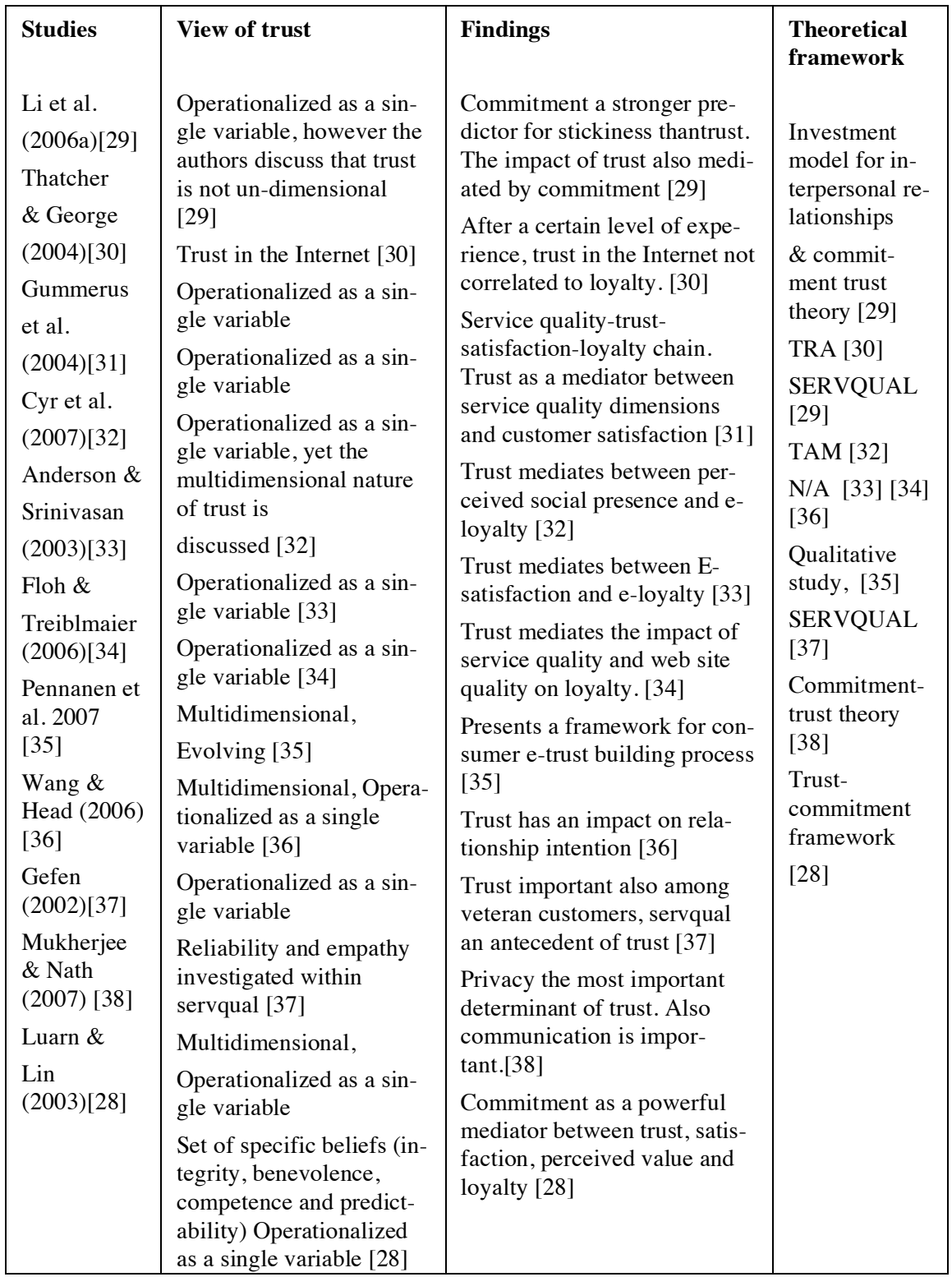


Table 3. B2C e-commerce literature reviews on trust

\begin{tabular}{|c|c|c|}
\hline Studies & View of trust & Findings \\
\hline Wang \& Emuri- & Multidimensional, & Framework for trust inducing features [24] \\
\hline $\begin{array}{l}\text { Tan \& Sutherland } \\
\text { (2004)[25] }\end{array}$ & $\begin{array}{l}{[24][2][27][25]} \\
\text { Proposed operation- } \\
\text { alization one- } \\
\text { dimensional }[26]\end{array}$ & $\begin{array}{l}\text { In IS literature, trust is often seen as one- } \\
\text { dimensional, only focusing on the interper- } \\
\text { sonal aspect, ignoring the dispositional and } \\
\text { institutional dimension. [25] }\end{array}$ \\
\hline $\begin{array}{l}\text { Holsapple \& Sasid- } \\
\text { haran[26] }\end{array}$ & $\begin{array}{l}\text { Multidimensional, } \\
\text { Dynamic [5] }\end{array}$ & $\begin{array}{l}\text { Proposes a research model that includes } \\
\text { subjective norm, computer anxiety and } \\
\text { computer self-efficacy to the TAM frame- } \\
\text { work. [26] }\end{array}$ \\
\hline $\begin{array}{l}\text { Grabner-Kräuter \& } \\
\text { Kaluscha (2003) [5] }\end{array}$ & & $\begin{array}{l}\text { Conceptual challenges in empirical stud- } \\
\text { ies, different definitions \& concepts, com- }\end{array}$ \\
\hline McKnight \& & & paring empirical studies difficult [5] \\
\hline Chervany & & $\begin{array}{l}\text { Comprehensive conceptualization of trust } \\
\text { [2] }\end{array}$ \\
\hline $\begin{array}{l}\text { Kim et al. } \\
(2005)[27]\end{array}$ & & $\begin{array}{l}\text { Comparison of academics' and practitio- } \\
\text { ners' perspectives of trust. Content analy- } \\
\text { sis, semantic network analysis. [27] }\end{array}$ \\
\hline
\end{tabular}


Table 4. G2IS e-government literature discussing trust

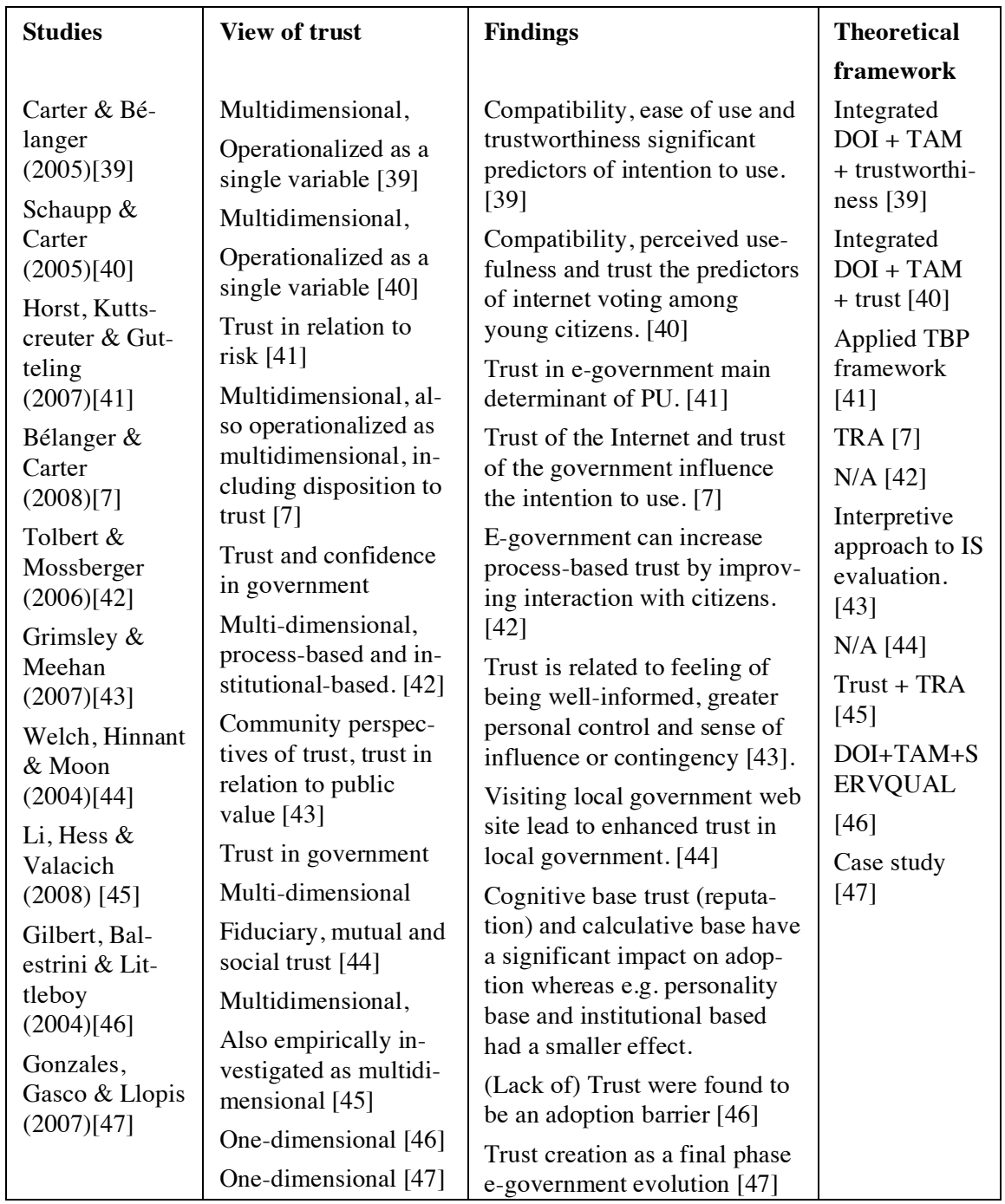




\section{Discussion}

\section{Implications for research and practice}

E-government is still a relatively new area of research. The first e-government articles presented in this paper were published in 2004. Thus, compared to rather large number of studies on trust within the e-commerce field of research, the trust discussion within the e-government domain is relatively meagre.

As stated earlier, the complex nature and challenges in defining of trust have been articulated by several authors. [cf. e.g. 5; 48] As articulated by e.g. McKnight et al. 2001 , trust can be viewed to have dispositional, interpersonal and institutional dimensions and neither of these dimensions is by nature monolithic. Despite most of the authors acknowledge the fact that trust is a multi-dimensional construct, in most of the listed e-commerce studies trust is operationalized as a single variable. In the egovernment field, relatively more studies empirically investigate trust as a multidimensional construct. This interesting finding may be explained by the fact that the research on trust within the e-government domain has benefited from prior trust research within e-commerce and e-services.

In the reviewed e-government literature, two main areas of trust discussion were identified. Trust in e-government [cf. e.g. 39] refers to individuals' perception of the trustworthiness of the technology used in producing and delivering the governmental service whereas trust in government [cf. e.g. 42; 44; 49] reflects individuals' perception on trustworthiness of the government in a wider perspective, including the political system and administration.

In the e-commerce literature, trust has been extensively discussed in relation to adoption.[10] However, particularly the recent e-commerce research includes examples of studies investigating trust also related to continuous use and customer loyalty. [cf. e.g. 13; 29] In the e-government literature the emphasis has so far been rather on exploring the adoption than continuous use of e-government services. This can be explained by the fact that the e-government per se is a relatively new phenomenon and therefore, investigating citizens' initial adoption is of particular importance. When looking back to the early days of trust research within the e-commerce domain, which is a more mature field of research, one can interpret that e-government research will evolve similarly from adoption towards focusing more on continuous use.

As regards the theoretical frameworks, multiple background theories have been used in the reviewed studies. In the presented e-commerce studies, quantitative analysis and literature reviews are in an important position. Quantitative research methods dominate also the reviewed e-government literature on trust. The e-government studies largely utilize the conceptualizations of trust from the e-commerce literature which may explain the lack of literature reviews focusing on trust in the e-government literature.

From a managerial perspective, trust is an issue of great significance in both acommerce and e-government areas, influencing not only the initial adoption but also 
the subsequent phases of the customer relationship. Since the role of trust evolves, it is a dynamic construct. Developing differentiated means for nurturing trust for novice and experienced users could potentially help to built enduring relationships with the users.

E-government has reported to provide several benefits from both the citizens' and government's perspective in form of costs savings and improving the availability of the service. (cf. e.g. Gonzales et al. 2007.)[47] Moreover, as stated by e.g. Welch et al. (2005) [44], use of e-government can increases citizens' overall trust in government. As trust has been identified to have an influence on e-commerce adoption, building trust is an important issue also from a managerial perspective.

\section{Limitations}

As with every research, also this study has its limitations. First of all, the risk with literature reviews is that important contributions are for some reason not included in the scrutiny. To reduce this risk, a systematic review of two dedicated e-government journals was conducted. However, since the e-government discussion is fragmented across several journals, the systematic approach did not create much additional value.

As the focus of this study was more on the e-government side, only a fraction of trust literature from e-commerce domain was selectively included in this review. Since both e-commerce and e-government are published on same forums, conducting a systematic review of e.g. ten key e-commerce journals would be a natural step to continue this path of research.

\section{Directions for future research}

This paper has investigated trust discussion in e-commerce and e-government fields. A potential avenue for further investigation would be to include e-health in the focus of the study. This could provide a more comprehensive picture of the trust discussion in the e-area.

One potential avenue to enrich the view of trust in the e-government domain would be to investigate trust from political science perspective. Introducing the concept of power from political science would potentially offer insight on how power and authority influence may trust in the e-government context.

Since trust is a dynamic construct, its role probably evolves after the initial adoption has taken place. So far, only very studies have done systematic attempts to investigate the dynamics of trust.

Moreover, attempts to put a price tag on trust would be interesting, i.e. what cost and/or benefit of nurturing trust. This issue has been investigated to some extent related to electronic marketplaces [50] but not extensively related to e-government. Thus, gaining a better understanding on the financial consequences of trust would be an insightful avenue for research also in the e-government domain. 


\section{Conclusions}

The aim of the paper was to review B2C e-commerce and e-services and G2IS egovernment trust literature in order to find differences as well as common denominators that could identify potential paths for further research and help to understand the present state of trust discussion within the two domains. The reviewed trust literature was divided into four categories, findings were discussed from a theoretical and managerial perspective and avenues for additional research suggested.

\section{References}

1. Bhattacherjee, A. (2002). Individual trust in online firms: Scale development and initial test. Journal of Management Information Systems, 19(1), 211-241.

2. Mcknight, D. H. (2001). What trust means in E-commerce customer relationships: An interdisciplinary conceptual typology. International Journal of Electronic Commerce, 6(2), 35-59.

3. Pavlou, P. A. (2003). Consumer acceptance of electronic commerce: Integrating trust and risk with the technology acceptance model. International Journal of Electronic Commerce, 7(3), 101-134.

4. Pavlou, P. A., \& Fygenson, M. (2006). Understanding and predicting electronic commerce adoption: An extension of the theory of planned behavior. MIS Quarterly, 30(1), 115-143.

5. Grabner-Kräuter, S., \& Kaluscha, E. A. (2003). Empirical research in on-line trust: A review and critical assessment. International Journal of Human-Computer Studies, 58(6), 783-812.

6. McKnight, D. H. (2002). Developing and validating trust measures for e-commerce: An integrative typology. Information Systems Research, 13(3), 334-359.

7. Bélanger, F., \& Carter, L. Trust and risk in e-government adoption. The Journal of Strategic Information Systems, In Press, Corrected Proof

8. Belanger, F., \& Hiller, J. S. (2006). A framework for e-government: Privacy implications. Business Process Management Journal, 12(1), 48.

9. Lee, S. M., Tan, X., \& Trimi, S. (2005). Current practices of leading e-government countries. Association for Computing Machinery.Communications of the ACM, 48(10), 99.

10. Cheung, C. M. K. (2005). A critical review of online consumer behavior: Empirical research. Journal of Electronic Commerce in Organizations, 3(4), 1-19.

11. Jasperson, J. (., Carter, P. E., \& Zmud, R. W. (2005). A comprehensive conceptualization of post-adoptive behaviors associated with information technology enabled work systems. MIS Quarterly, 29(3), 525-557.

12. Venkatesh, V. (2003). User acceptance of information technology: Toward a unified view. MIS Quarterly, 27(3), 425-478.

13. Premkumar, G., \& Bhattacherjee, A. (2008). Explaining information technology usage: A test of competing models. Omega, 36(1), 64-75.

14. Bhattacherjee, A. (2001). An empirical analysis of the antecedents of electronic commerce service continuance. Decision Support Systems, 32(2), 201-214.

15. Bhattacherjee, A. (2001). Understanding information systems continuance: An expectationconfirmation model. MIS Quarterly; Minneapolis, 25(3), 351-370.

16. Parthasarathy, M. (1998). Understanding post-adoption behavior in the context of online services. Information Systems Research, 9(4), 362-379.

17. Spiller, J., Vlasic, A., \& Yetton, P. (2007). Post-adoption behavior of users of internet service providers. Information \& Management, 44(6), 513-523. 
18. Webster, J., \& Watson, R. T. (2002). Analyzing the past to prepare for the future: Writing a literature review. MIS Quarterly, 26(2), 13-23.

19. Lim, K. H., Sia, C. L., Lee, M. K. O., \& Benbasat, I. (2006). Do I trust you online, and if so, will I buy? an empirical study of two trust-building strategies. Journal of Management Information Systems, 23(2), 233-266.

20. Hampton-Sosa, W., \& Koufaris, M. (2005). The effect of web site perceptions on initial trust in the owner company. International Journal of Electronic Commerce, 10(1), 55-81.

21. Gefen, D., Karahanna, E., \& Straub, D. W. (2003). Trust and TAM in online shopping: An integrated model. MIS Quarterly; Minneapolis, 27(1), 51-90.

22. Gefen, D., \& Straub, D. W. (2003). Managing user trust in B2C e-services. E - Service Journal; Bloomington, 2(2), 7.

23. Pavlou, P. A., Huigang Liang, \& Yajiong Xue. (2007). Understanding and mitigating uncertainty in online exchange relationships: A principal--agent perspective. MIS Quarterly, 31(1), 105-136.

24. Wang, Y. D., \& Emurian, H. H. (2005). An overview of online trust: Concepts, elements, and implications. Computers in Human Behavior, 21(1), 105-125.

25. Tan, F. B., \& Sutherland, P. (2004). Online consumer trust: A multi-dimensional model. Journal of Electronic Commerce in Organizations, 2(3), 40.

26. Holsapple, C. W., \& Sasidharan, S. (2005). The dynamics of trust in B2C e-commerce: A research model and agenda. Information Systems and eBusiness Management, 3(4), 377.

27. Kim, D. J., Song, Y. I., Baynov, S. B., \& Rao, H. R. (2005). A multidimensional trust formation model in B-to-C e-commerce: A conceptual framework and content analyses of academia/practitioner perspectives. Decision Support Systems, 40(2), 143.

28. Luarn, P., \& Lin, H. (2003). A customer loyalty model for E-service context. Journal of Electronic Commerce Research, 4(4), 156-167.

29. Li, D., Browne, G. J., \& Chau, P. Y. K. (2006). An empirical investigation of web site use using a commitment-based model. Decision Sciences, 37(3), 427-444.

30. Thatcher, J. B., \& George, J. F. (2004). Commitment, trust, and social involvement: An exploratory study of antecedents to web shopper loyalty. Journal of Organizational Computing and Electronic Commerce, 14(4), 243.

31. Gummerus, J., Liljander, V., Pura, M., \& van Riel, A. (2004). Customer loyalty to content-based web sites: The case of an online health-care service. The Journal of Services Marketing, 18(2/3), 175.

32. Cyr, D. The role of social presence in establishing loyalty in e-service environments. Interacting with Computers, 19(1), 43-56.

33. Anderson, R. E., \& Srinivasan, S. S. (2003). E-satisfaction and E-loyalty: A contingency framework. Psychology \& Marketing, 20(2), 123-138.

34. Floh, A., \& Treiblmaier, H. (2006). What keeps the E-banking customer loyal? a multigroup analysis of the moderating role of consumer characteristics on E-loyalty in the financial service industry. Journal of Electronic Commerce Research, 7(2), 97.

35. Pennanen, K., Tiainen, T., \& Luomala, H. T. (2007). A qualitative exploration of a consumer's value-based e-trust building process. Qualitative Market Research, 10(1), 28.

36. Wang, F., \& Head, M. (2007). How can the web help build customer relationships?: An empirical study on e-tailing. Information \& Management, 44(2), 115.

37. Gefen, D. (2002). Customer loyalty in E-commerce. Journal of the Association for Information Systems, 3, 27-51.

38. Mukherjee, A., \& Nath, P. (2007). Role of electronic trust in online retailing. European Journal of Marketing, 41(9), 1173-1202.

39 Carter, L., \& Bélanger, F. (2005). The utilization of e-government services: Citizen trust, innovation and acceptance factors. Information Systems Journal, 15(1), 5-25.

40 Schaupp, L. C., \& Carter, L. (2005). E-voting: From apathy to adoption. Journal of Enterprise Information Management, 18(5/6), 586. 
41 Horst, M., Kuttschreuter, M., \& Gutteling, J. M. (2007). Perceived usefulness, personal experiences, risk perception and trust as determinants of adoption of e-government services in the netherlands. Computers in Human Behavior, 23(4), 1838-1852.

42 Tolbert, C. J., \& Mossberger, K. (2006). The effects of E-government on trust and confidence in government. Public Administration Review, 66(3), 354.

43 Grimsley, M., \& Meehan, A. (2007). e-government information systems: Evaluation-led design for public value and client trust. European Journal of Information Systems, 16(2), 134.

44 Welch, E. W. (2005). Linking citizen satisfaction with E-government and trust in government. Journal of Public Administration Research and Theory, 15(3), 371.

$45 \mathrm{Li}$, X., Hess, T. J., \& Valacich, J. S. Why do we trust new technology? A study of initial trust formation with organizational information systems. The Journal of Strategic Information Systems, In Press, Corrected Proof

46 Gilbert, D., Balestrini, P., \& Littleboy, D. (2004). Barriers and benefits in the adoption of egovernment. The International Journal of Public Sector Management, 17(4/5), 286.

47 Gonzalez, R., Gasco, J., \& Llopis, J. (2007). E-government success: Some principles from a spanish case study. Industrial Management + Data Systems, 107(6), 845.

48 Cowles, D. L. (1997). The role of trust in customer relationships: Asking the right questions. Management Decision, 35(4), 273-282.

49 West, D. M. (2004). E-government and the transformation of service delivery and citizen attitudes. Public Administration Review, 64(1), 15.

50 Pavlou, P. A., \& Dimoka, A. (2006). The nature and role of feedback text comments in online marketplaces: Implications for trust building, price premiums, and seller differentiation. Information Systems Research, 17(4), 392-414. 